\title{
STRATEGI BAZNAS DALAM MENGATASI KETIMPANGAN PENERIMAAN DANA ZAKAT (STUDI KASUS : BAZNAS KABUPATEN SANGGAU KALIMANTAN BARAT)
}

\author{
Rahmah Yulisa Kalbarini ${ }^{1}$, Muhammad Amin Zaki $^{2}$ \\ Institut Agama Islam Negeri Pontianak ${ }^{1,2}$ \\ rinikalbarini@yahoo.com ${ }^{1}$ m.aminzaki21@gmail.com ${ }^{2}$
}

\begin{abstract}
Strategy of BAZNAS to Resolve Inequality of Zakat Fund Receipts (Case Study: BAZNAS, Sanggau District, West Kalimantan) is a descriptive qualitative research that is a study that describes the facts that exist in the field in the form of text, because to capture a deep understanding not only through data in the form of number. Data collection tools are the method of observation, interviews, documentation, and library research. The purpose of this research is to find out: 1) The practice of the distribution of zakat funds to the community in Sanggau Regency 2) The solution in overcoming the inequality of the receipt of zakat funds from the community of Sanggau District. The results of the study were first, the distribution of zakat funds in the Sanggau District Baznas was distributed to the poor, poor, Ibn Sabil, amil, and reverts. This is according to Imam Shafi'i, alms must be given eight groups if any. If not, zakat is only given to existing ones. Second, zakat funds must also be distributed evenly and regularly, especially for the poor so that they can make a living. Third, increasing the effectiveness of distribution so that the funds raised can be felt by all mustahik. Based in the above research, the author can provide suggestions for increasing the collection of funds so that the distribution of zakat funds is greater. Thus there will be no imbalance in the receipt of zakat funds on mustahik.
\end{abstract}

Keywords : Strategy, Zakat Fund, Distribution

\section{PENDAHULUAN}

Ketimpangan pendapatan merupakan salah satu permasalahan yang di hadapi Indonesia. Menurut data dari BPS pada bulan Maret 2020 ketimpangan pendapatan yang diukur oleh gini ratio tercatat 0,381 naik 0,001 dari September 2019 sebesar 0,380. Dampak dari ketimpangan pendapatan ini menurut Sugiyarto, et all (2015) salah satunya adalah tingginya tingkat kemiskinan. Semakin tinggi tingkat ketimpangan pendaptan menyebabkan tingkat kemiskinan yang semakin meningkat pula. Permasalahan ketimpangan pendapatan ini menurut Ekonom Indonesia Yusuf Rendy Menilet dikutip dari Republika disebabkan oleh berbagai aspek diantaranya aspek tenaga kerja dan perpajakan. Beberapa tenaga kerja yang dapat meningkatkan skillnya menyebabkan tingkat upahnya meningkat. Namun lainnya yang memiliki skill rendah tingkat upah rendah sehingga ketimpangan pendapatan tinggi. Aspek lainnya yang menyebabkan ketimpangan 
pendapatan adalah pajak yang relative tidak merata sehingga menimbulkan ketimpangan pendapatan.

Dalam Islam, masalah ketimpangan pendapatan dapat diatasi dengan berbagai cara, salah satunya adalah zakat. Zakat dalam ekonomi berperan mencegah terjadinya penumpukan kekayaan pada segelintir orang dan mendistribusikan harta yang mereka miliki kepada orang yang membutuhkan. Selain itu, zakat juga dapat mengurangi tingkat kemiskinan jika zakat dikelola dan didistribusikan dengan baik dan tepat sasaran kepada orang yang membutuhkan (rozalinda, 2016). Zakat tidak akan berjalan efektif dan memberikan manfaat yang besar bagi penerimanya jika tidak dikelola dan didistribusikan dengan adil. Keadilan distribusi dalam zakat penting untuk dilakukan mengingat distribusi zakat merupakan bagian dari bentuk tanggungjawab pengelolaan 'amil, sehingga keadilan ini adalah suatu hal yang mutlak untuk diusahakan dan menjadi target dalam setiap penyusunan program untuk pendistribusian zakat kepada mustahiq (abror:2019). Selain itu, dalam tatanan makro, keadilan distribusi zakat dapat meningkatkan permintaan barang dan jasa bagi masyarakat dikarenakan dana zakat yang diberikan oleh mereka yang memiliki pendapatan yang besar kepada masayarakat berpenghasilan rendah dapat digunakan untuk memenuhi kebutuhan primer (Mukaromah:117)

Di Indonesia, zakat dikelola oleh lembaga pemerintah dan swasta. Lembaga pemerintah yang bertugas mengumpulkan, mengelola dan mendistribusikan Zakat adalah Badan Amil Zakat Nasional (BAZNAS). BAZNAS tersebar hampir diseluruh kabupaten/kota di seluruh Indonesia. Tidak terkecuali di kabupaten sanggau, Kalimantan Barat. BAZNAS kabupaten Sanggau termasuk BAZNAS kabupaten terbesar di Kalimantan Barat. Hal ini terlihat dari data penghimpunan dan penyaluran dana Zakat yang di BAZNAS kabupaten Sanggau:

Tabel 1. Rekapitulasi Penghimpunan dan Penyaluran Zakat Baznas Sanggau

\begin{tabular}{lllll}
\hline Tahun & Muzakki & Mustahik & Penghimpunan & Penyaluran \\
\hline $\mathbf{2 0 1 8}$ & 194 & 593 & 388.871 .368 & 293.850 .000 \\
$\mathbf{2 0 1 9}$ & 241 & 638 & 411.591 .767 & 398.315 .000 \\
\hline
\end{tabular}

Sumber : Baznas Kabupaten Sanggau

Kabupaten Sanggau merupakan salah satu wilayah di provinsi Kalimantan Barat yang memiliki luas wilayah $12.858 \mathrm{~km} 2$ dan terdiri dari 15 kecamatan. Penduduk Sanggau pada tahun 2019 sebanyak 470.224 jiwa dan penduduk muslim sebanyak 164.969 jiwa. Potensi zakat yang dimiliki kabupaten Sanggau terbilang cukup besar mengingat hamper 30\% warganya merupakan 
warga muslim. Banyaknya jumlah kecamatan yang tersebar di Kabupaten Sanggau menuntut adanya keadilan distribusi zakat disetiap wilayah agar terjadi pemerataan pendapatan masyarakat.

\section{LITERATURE REVIEW}

Rozalinda (2014) Zakat secara bahasa berarti an-nuwu wa az-ziyadah (tumbuh dan berkembang). Zakat secara istilah berarti mengeluarkan bagian tertentu dari harta yang telah sampai nisabnya untuk orang-orang yang berhak menerimanya. Selain itu, definisi lain dari zakat adalah pemindahan pemilikan harta tertentu untuk orang yang berhak menerimanya dengan syarat-syarat tertentu. Peran zakat dalam bidang ekonomi adalah zakat dapat mencegah terjadinya penumpukan kekayaan pada segelintir orang saja dan mewajibkan orang kaya untuk mendistribusikan harta kekayaannya pada orang mskin. Zakat merupakan sumber dana potensial untuk mengentaskan kemiskinan.

Islam menjadikan instrument zakat untuk memastikan keseimbangan pendapatan di masyarakat. Keseimbangan pendapatan di masyarakat dapat terwujud dengan adanya keadilan distribusi zakat kepada masyarakat yang membutuhkan. Bentuk distribusi zakat dibedakan menjadi empat yaitu, distribusi bersifat konsumsi tradisional yaitu zakat diberikan langsung kepada mustahik untuk memenuhi kebutuhan sehari-harinya. Distribusi bersifat konsumsi kreatif dimana zakat diberikan untuk peralatan sekolah. Distribusi bersifat produktif tradisional dimana zakat diberikan dalam bentuk barang-barang produktif yang bisa menciptakan lapangan pekerjaan bagi fakir miskin seperti hewan ternak dan distribusi bersifat produktif kreatif yaitu zakat dalam bentuk modal kerja bagi pedagang atau usaha kecil.

Mustahik adalah orang yang berhak menerima zakat berdasarkan Al-Quran surat AtTaubah ayat 60 yang menjelaskan bahwa penerima zakat terdiri dari :

1. Fakir Menurut Soemitra (2009) Fakir adalah orang yang penghasilannya tidak dapat memenuhi kebutuhan pokok (primer) sesuai dengan kebiasaan masyarakat tertentu atau orang yang tidak memiliki harta dan penghasilan yang halal dalam pandangan jumhur ulama fikih dan yang mempunyai harta yang kurang dari nizab zakat. Fakir orang yang sama sekali tidak memiliki pekerjaan atau orang yang memiliki pekerjaan tetapi tidak mampu memenuhi kebutuhan pokok yang layak bagi kemanusiaan.

2. Miskin adalah orang-orang yang memerlukan, yang tidak dapat menutupi kebutuhan pokoknya sesuai dengan kebiasaan yang berlaku. Miskin menurut mayoritas ulama adalah orang yang tidak memiliki harta dan tidak mempunyai pencarian yang layak untuk memenuhi kebutuhannya. Menurut Imam Abu Hanifah, miskin adalah orang yang tidak memiliki sesuatu. Menurut Mazhab Hanafi dan Maliki, keadaan mereka lebih buruk dari 
orang fakir, sedangkan menurut Mazhab Syafi'i dan Hambali, keadaan mereka lebih baik dari orang yang fakir.Bagi mereka berlaku hukum yang berkenaan dengan mereka yang berhak menerima zakat (Soemitra, 2009).

3. Amil Zakat. Adapun amil zakat adalah semua pihak yang bertindak mengerjakan yang berkaitan dengan pengumpulan, penyimpanan, penjagaan, pencatatan, dan membagikan iokserta tugas lain yang berhubungan dengan zakat, seperti penyadaran masyarakat tentang hukum zakat, menerangkan sifat-sifat pemilik harta yang terkena kewajiban membayar zakat dan mereka yang mustahik, mengalihkan, menyimpan dan menjaga serta meninvestasikan harta zakat sesuai dengan ketentuan (Soemitra, 2009).

4. Muallaf. Adapun yang termasuk dalam kategori mualaf ini adalah Pertama, orang-orang yang dirayu untuk memeluk Islam: sebagai persuasi terhadap hati orang yang diharapkan akan masuk Islam atau keislaman orang yang berpengaruh untuk kepentingan Islam dan umat Islam. Kedua, orang-orang yang dirayu untuk membela umat Islam.Ketiga, orangorang yang baru masuk Islam kurang dari satu tahun yang masih memerlukan bantuan dalam beradaptasi dengan kondisi baru mereka meskipun tidak berupa pemberian nafkah, atau dengan mendirikan lembaga keilmuan dan sosial yang akan melindungi dan memantapkan hati mereka dalam memeluk Islam (Soemitra, 2009).

5. Hamba Sahaya Itu adalah dana zakat yang digunakan untuk memerdekakan dirinya sendiri dari berbagai macam perbudakan. Saat ini riqab tidak ada lagi, maka kuota zakat mereka dialihkan ke golongan mustahik lain menurut pendapat mayoritas ulama fikih (jumhur). Namun sebagian ulama berpendapat bahwa golongan ini masih ada, yaitu para tentara muslim yang menjadi tawanan (Soemitra, 2009).

6. Orang yang Berhutang (Gharim) Orang yang berhutang untuk keperluan pribadi untuk kehidupan karena kebutuhan mendesak. Kesulitan untuk melunasi hutang dalam jangka waktu yang sudah ditentukan.

7. Fisabilillah Seseorang atau kelompok yang berada dijalan Allah SWT menyebarkan agama islam atau memakmurkan tempat ibadah serta mengajak orang-orang untuk beribadah.

8. Ibnu Sabil Orang yang sedang berada di perjalanan dan membutuhkan bantuan atau mengalami kemalangan dalam perjalanannya

Distribusi zakat yang dilakukan kepada mustahik haruslah berdasarkan skala prioritas mengingat keterbatasan sumber dana yang ada. Skala prioritas dalam distribusi zakat dilihat dari skala prioritas mustahik. Jika mustahik merupakan fakir yang tidak dapat memiliki pekerjaan dan penghasilan, maka diberi bantuan dana zakat berupa uang tunai atau barang kebutuhan sehari- 
hari sedangkan bagi mustahik yang memiliki keahlian khusus namun kesulitan dalam mendapatkan dana maka zakat dpaat disalurkan dalam bentuk modal kerja.

Badan Amil Zakat Nasional (BAZNAS) yang bertugas menghimpun zakat dari muzakki dan menyalurkannya kepada mustahik juga dituntut untuk melakukan distibusi zakat dengan adil kepada mustahik. Menurut Beik (2016) dalam perpektif muzakki keadilan distribusi dapat dinilai dari informasi yang jelas mengenai data mustahik, area distribusi yang merata dan kinerja BAZNAS. Informasi yang jelas mengenai mustahik dapat meminimalkan distribusi zakat yang tidak adil kepada mustahik. Area distibusi zakat yang merata diharapkan dapat dilakukan agar tidak terjadi ketimpangan pendapatan antara daerah satu dengan lainnya. Kinerja BAZNAS juga menjadi penilaian bagi muzakki karena apabila kinerja BAZNAS baik maka muzakki akan memberikan dana zakat kepada BAZNAS.

\section{METODOLOGI}

Menurut Sugiyono (2011), Metode penelitian kualitatif merupakan metode penelitian yang berlandas-kan pada filsafat positivisme, digunakan untuk meneliti pada kondisi obyek yang alamiah, (sebagai lawannya adalah eksperimen) dimana peneliti adalah sebagai instrumen kunci, pengambilan sampel sumber data dilakukan secara purposive dan snowbaal, teknik pengumpulan dengan trianggulasi, analisis data bersifat induktif/kualitatif, dan hasil penelitian kualitatif lebih menekan makna dari pada generalisasi. Penelitian yang digunakan dalam penelitian ini adalah deskriptif kualitatif karena data yang ada atau disajikan dalam penelitian ini berupa teks untuk menangkap maksud yang mendalam tidak hanya melalui data berupa angka. Penelitian deskriptif kualitatif digunakan karena penelitian ini bermaksud untuk memaparkan keadilan distribusi dana zakat di Baznas Kabupaten Sanggau.

Teknik pengambilan data dalam penelitian ini melalui observasi langsung ke Kantor Baznas Kabupaten Sanggau dan rumah mustahik penerima dana zakat. Selain itu, peneliti juga melakukan wawancara kepada pihak Baznas dan mustahik penerima dana zakat serta peneliti melakukan dokumentasi yang berhubungan dengan penelitian ini. Triangulasi data dalam penelitian ini dilakukan dengan cara peneliti melakukan wawancara kepada pihak Baznas yang dalam penelitian ini diwakilli oleh ketua bagian distribusi zakat kemudian peneliti melakukan pengecekan kembali jawaban pihak Baznas kepada sepuluh orang mustahik penerima dana zakat. 


\section{HASIL DAN PEMBAHASAN}

\section{Praktik Distribusi Dana Zakat Kepada Masyarakat Kabupaten Sanggau}

Berdasarkan hasil wawancara terhadap pihak Baznas dan beberapa mustahik ada beberapa langkah dalam mendistribusikan dana zakat kepada masyarakat.

a. Muzaki Membayar Zakat ke BAZNAS Pada awalnya muzaki yaitu pemilik harta yang diwajibkan membayar zakat atas kepemilikan harta memberikan zakat langsung ke BAZNAS atau pihak BAZNAS mendatangi rumah muzaki untuk mengambil uangnya. Para muzaki bisa membayarkan zakatnya perbulan agar tidak terasa banyak jumlah yang dikeluarkan untuk zakat.

b. Pengumpulan Dana Zakat oleh BAZNAS Pihak BAZNAS melakukan pengumpulan dana zakat selama tiga bulan atau kurang dan jika sudah mencapai sekitar 100 juta dana zakat akan langsung di distribusikan. Sehingga dana yang ada tidak terlalu banyak atau sedikit saat mau didistribusikan.

c. Distribusikan Zakat ke Mustahik Melalui program-program BAZNAS maka dana zakat akan langsung di distribusikan kebeberapa mustahik ada yang dipanggil datang ke BAZNAS untuk diberikan langsung dana zakatnya dan ada langsung BAZNAS datang ke tempat mustahik yang sudah di data sebelumnya.

Baznas menerima data-data mustahik atau orang yang memerlukan zakat itu berdasarkan info dari masyarakat yang menginformasikan kepada BAZNAS. Ada juga beberapa data mustahik yang didapat dari hasil survei di daerah yang memerlukan zakat. Kebanyakan mustahik yang mendapat zakat mereka tidak mengetahui bahwa mereka dapat dana zakat berupa uang. Tetapi BAZNAS secara langsung mendatangi mustahik dan memberikan zakat kepada mereka. Sehingga tidak ada koordinasi antara BAZNAS dan mustahik dalam kegiatan praktik distribusi dana zakat yang pihak mustahiknya didatangi langsung kerumahnya. BAZNAS memiliki beberapa program yang diantaranya dapat dijadikan salah satu sarana dalam mempublikasikan pentingnya untuk berzakat dengan demikian maka akan lebih banyak orang yang sadar akan zakat dan pengumpulan zakat juga akan meningkat sehingga dapat menambah program-program agar BAZNAS menjadi lebih baik lagi.

Distribusi zakat di BAZNAS diklasifikan berdasarkan kebutuhan mustahik. Mustahik yang tergolong miskin yang memiliki anak usia sekolah maka akan mendapat bantuan dari BAZNAS berupa biaya sekolah atau kebutuhan sehari-hari. Mustahik yang berusia di atas 50 tahun yang tidak dapat memenuhi kebutuhan sehari-hari maka digolongkan sebagai asnaf fakir dan bantuan yang diberikan BAZNAS merupakan barang konsumtif untuk kebutuhan sehari-hari 
yang diantar langsung ke rumah mustahik. Berdasarkan orang yang berhak menerima zakat menurut mazhab syafi'i dan hambali orang fakir adalah mereka yang tidak memiliki harta benda dan pekerjaan yang mampu mencukupi kebutuhan sehari-harinya sehingga mereka butuh zakat untuk melanjutkan hidupnya. Dari kalangan ini perlu zakat yang teratur guna mencukupi kebutuhannya sehingga dalam praktik distribusinya mustahik yang berusia diatas 50 tahun harus diutamakan dalam diberi zakat.

Distribusi zakat selanjutnya haruslah dapat dibagi rata ke program-program yang lain sebab yang paling penting adalah membagi dana zakat ke para mustahik agar penerimaan dana zakatnya terbagi rata. Karena kebutuhan setiap mustahik pasti berbeda beda. Fakta di lapangan mustahik mengeluh waktu penerimaan dana zakatnya yang tidak teratur sehingga mereka terkadang tidak makan dan mengharapkan bantuan tetangga untuk makan. Diharapkan mustahik yang berusia diatas 50 tahun lebih diutamakan untuk mendapat dana bantuan dari BAZNAS.

\section{Solusi Mengatasi Ketimpangan Penerimaan Dana Zakat pada Masyarakat Kabupaten Sanggau}

Potensi zakat yang ada itu sangat besar akan tetapi kenyataan yang ada hanya beberapa persen saja yang membayar zakat dan terdata oleh pihak Baznas. Masih banyaknya para muzakki yang membayar zakat langsung ke mustahik tanpa adanya koordinasi dengan pihak Baznas menjadi kendala tersendiri bagi BAZNAS dalam mengumpulkan dana zakat. Selain itu, muzakki yang membayar langsung dana zakatnya ke mustahik dapat mengurangi ketimpangan pendapatan di antara mustahik.

Solusi yang paling baik dalam mengatasi ketimpangan penerimaan dana zakat pada masyarakat Kabupaten Sanggau (mustahik) Menurut Eri Sudewo (2004) adalah dari sisi manajemen pengelola zakat dapat dilihat dari manajemen penggalangan dana dan manajemen layanan donator. Manajemen penggalangan dana yang dimaksud adalah :

a. Kampanye. Proses ini dalah bagian dari proses untuk membangkitkan kesadaran membayar zakat. kampanye menjadi salah satu bagian yang palin penting untuk dilakukan. Kampanye bisa dilakukan dengan berbagai cara seperti sosialisasi melalui Media massa, film/video, portal website dan lain-lain.

Sosialisasi diperlukan agar masyarakat lebih mengenal zakat sebagai kewajiban dalam rukun Islam dan juga membantu masyarakat atau mustahik yang membutuhkan zakat. Diharapkan dengan adanya kampanye atau sosialisasi ini dapat meningkatkan kepercayaan masyarakat sehingga masyarakat yang wajib zakat akan membayar zakat langsung ke Baznas dan tidak akan terjadi ketimpangan penerimaan dana zakat pada 
setiap mustahik yang terjadi karena ada pemberian dana zakat ganda antara muzakki dan Baznas.

b. Kerjasama program. Kerjasama dapat juga dilaksanakan lewat kerjasama lembaga atau organisasi yang berbentuk perusahaan ataupun yang berbentuk fundrising.

c. Seminar dan diskusi dalam rangka sosialisasi zakat, galang dana atau menghimpun dengan cara melakukan seminar dan diskusi dengan dibuat tema yang relevan dengan kegiatan dan kiprah OPZ.

d. Pemanfaatan rekening bank bermaksud memberikan kemudahan donatur menyalurkan dana.

Sedangkan manajemen layanan donatur yang dapat dilakukan antara lain:

a. Melakukan pendataan calon donatur atau donatur tetap dengan diimbangi sistem dokumentasi yang rapi.

b. Menerima dan memberikan solusi keluhan donatur dan masyarakat secara meluas.

c. Follow up keluhan-keluhan yang datang dan mencari soslusi yang kongkrit Senada yang disampaikan

Solusi berikutnya yang dapat mengatasi ketimpangan penerimaan dana zakat pihak Baznas dapat dilihat dari kondisi mustahik. Pihak BAZNAS harus melakukan survei dan analisis lebih rinci kebutuhan dan tanggungan yang diperlukan mustahik sehingga dana zakat yang dikeluarkan sesuai kebutuhan mustahik dan penerimaan dana zakat mustahik terbagi rata sesuai keperluannya. Kebutuhan mustahik yang lebih utama diberikan zakat berdasarkan umur yaitu :

a. Manula $>65$ Tahun. Mustahik paling membutuhkan zakat adalah orang tua berumur lebih dari 65 tahun atau sudah tidak bisa berkerja lagi walaupun berkerja tidak dapat memenuhi kebutuhan sehari harinya dan mengharapkan bantuan orang lain. Mereka lebih diutamakan diberi zakat sehingga mereka seharusnya diberi zakat secara rutin untuk membeli kebutuhannya.

b. Lansia > 46-65 Tahun Mustahik pada usia ini Biasanya mereka memiliki pekerjaan akan tetapi memiliki tanggungan yang banyak sehingga terkadang memerlukan bantuan dana zakat untuk memenuhi kebutuhan sehari-hari. Pembagian zakat seharusnya berdasarkan pekerjaan dan tanggungan sehingga setiap mustahik mendapat zakat berbeda beda.

c. Remaja 12-25 Tahun. Pelajar yang menerima zakat ada dua kriteria yaitu mustahik yang masih memiliki orang tua dan yang yatim piatu. Jadi dalam pendistribusian dana zakat untuk memenuhi kebutuhan pelajar diharapkan pelajar yang tidak memiliki orang tua alias 
yatim piatu mendapat porsi yang lebih banyak daripada pelajar yang masih memiliki orang tua.

Kesimpulannya adalah mustahik yang paling mendapat prioritas mendapat dana zakat secara rutin adalah para manula karna termasuk dalam asnaf fakir yaitu mustahik yang membutuhkan dan mereka tidak bisa berkerja untuk memenuhi kebutuhannya. Prioritas berikutnya yang haus mendapat dana zakat adalah Lansia. Lansia yang masih bekerja namun hasilnya belum mencukupi untuk memenuhi kebutuhan sehari-hari juga wajib diberikan zakat. Prioritas terakhir adalah remaja. Remaja termasuk dalam para pelajar yang bersekolah namun masih kekurangan dana untuk biaya sekolah dan kebutuhan lainnya

Solusi lainnya untuk mengurangi ketimpangan penerimaan dana zakat dapat dilihat dari program yang ada di BAZNAS Kabupaten Sanggau yaitu :

a. Program Ekonomi. Program ini dilakukan agar dapat membantu masyarakat dalam meningkatkan perekonomian mereka dengan cara memberi modal dan membuat sosialisasi untuk meningkatkan SDM sehingga dapat membuat inovasi-inovasi baru sehingga ekonomi mereka dapat meningkat.

b. Program Pendidikan. Program pendidikan adalah program yang memberikan bantuan zakat kepada siswa-siwa yang membutuhkan dan agar meringankan beban orang tua siswa. Program ini juga diharapkan dapat membuat anak-anak di masa depan sadar akan berzakat sehingga semakin banyak orang yang berzakat.

c. Program Kesehatan. Program ini membantu masyarakat langsung yang membutuhkan bantuan di rumah sakit, puskesmas, atau apotik dalam membayar keperluannya seperti membeli obat, membayar BPJS, dll.

d. Program Advokasi Program ini dilakukan apabila masih ada tersisa dana Baznas dari infaq dan shadaqah untuk menyumbangkan uang ke lembaga yang membutuhkan dan termasuk dalam sosialisasi ke masyarakat bahwa Baznas menggunakan dana zakat secara maksimal.

Program layanan Baznas ini diharapkan dapat memenuhi kebutuhan mustahik dan meningkatkan kepercayaan muzakki kepada Baznas sehingga muzakki dapat membayar zakat langsung ke Baznas. Hal ini dilakukan untuk meminimalisir terjadinya ketimpangan penerimaan dana zakat dikarenakan dana zakat yang seharusnya dibagikan secara merata kepada setiap orang yang membutuhkan akan tetapi di lapangan terdapat mustahik yang mendapat dana zakat lebih banyak dan ada mustahik yang masih belum ada dapat sama sekali dana zakat. 
Kesimpulannya, Upaya mengatasi ketimpangan penerimaan dana zakat pada masyarakat dapat dilakukan, pertama dengan meningkatkan dana penghimpunan zakat seperti meningkatkan kampanye dan sosialisasi serta kerjasama dengan lembaga lain yang diharapkan dapat meningkatkan dana zakat yang ada di BAZNAS.

Kedua yaitu meningkatkan layanan donator seperti mendata calon donator dan donator tetap, mengatasi keluhan-keluhan yang dihadapi muzakki terkait dengan dana zakat seperti tidak tersedianya waktu para muzakki untuk dating langsung memberikan zakatnya ke BAZNAS sehingga dapat dibantu dengan penjemputan dana langsung dari rumah muzakki dan lain-lain.

Ketiga, penggolongan mustahik sesuai dengan kondisi, kebutuhan dan tanggungan. Dana zakat diharapkan dapat terdistribusi dengan merata dan tepat sasaran kepada mustahik yang membutuhkan. Oleh sebab itu, diperlukan penggolongan mustahik berdasarkan kondisi, kebutuhan serta tanggungan keluarga agar dana zakat dapat tepat sasaran sesuai dengan kebutuhan mustahik.

Keempat, mengadakan program-program yang dapat mengakomodir kebutuhan mustahik. Program ekonomi, kesehatan dan pendidikan diperlukan untuk memenuhi kebutuhan mustahik di bidang ekonomi, kesehatan dan pendidikan. Selain itu, diharapkan dengan programprogram yang ada di BAZNAS dapat meningkatkan kepercayaan masyarakat untuk memberikan dana zakatnya ke BAZNAS.

\section{SIMPULAN}

Berdasarkan Penelitian di lapangan, maka dapat diambil kesimpulan sebagai berikut: (i) Praktik distribusi dana zakat kepada masyarakat di Baznas Kabupaten Sanggau berjalan efekif karena dilakukan melalui proses yang telah ditetapkan yaitu Muzakki memberikan dana zakat kemudian pihak Baznas melakukan pengumpulan zakat dan mensurvei mustahik yang akan diberikan dana zakat. Setelah itu pihak Baznas memberikan langsung dana zakat yang sudah disiapkan melalui program-program yang ada kepada mustahik sehingga dana yang diberikan tepat sasaran, dan (ii) Ketimpangan dana zakat yang terjadi di BAZNAS Kabupaten Sanggau dikarenakan adanya beberapa faktor seperti manajemen penghimpunan dana zakat, manajemen layanan donator, penentuan mustahik dan program-program pendistribusian dana zakat. Kurangnya kampanye dan sosialisasi dana zakat membuat tidak optimalnya dana zakat yang ada di BAZNAS. Banyaknya muzakki yang langsung membayarkan dana zakatnya kepada mustahik membuat beberapa mustahik menerima bantuan zakat lebih dari satu kali dalam satu periode pendistribusian. Selain itu pendistribusian dana zakat juga tidak dilakukan secara rutin pertiga bulan kepada fakir yang sangat membutuhkan untuk kebutuhan hidupnya. Hal itu disebabkan 
minimnya dana zakat yang ada di BAZNAS. Penentuan mustahik yang tidak tepat juga membuat adanya ketimpangan penerimaan pendapatan dana zakat.

\section{REFERENSI}

Abror, Arsyad. (2019). Keadilan Distribusi dan Minat Bayar Zakat Melalui Organisasi Pengelola Zakat. Universitas Islam Indonesia.

Bungin, Burhan. (2015). Analisis Data Penelitian Kualitatif. Jakarta: Rajawali Pers Chalid, Nursiah dan

Dodik, Siswantoro dan Eka Satrio. (2016) “ Analis Faktor pendapatan, Kepercayaan dan Religiutas dalam mempengaruhi minat muzzaki untuk membayar zakat penghasilan melalui lembaga amil zakat". Lampung: Simposium Nasional Akuntasi XIX.

Hafidhuddin, Didin. (2002). Zakat Dalam Perekonomian Modern. Jakarta: Gema Insani Huda, dkk. (2015). Zakat Perspektif Mikro-Makro Pendekatan Riset. Jakarta: Prenamedina Group

Laras Ayu Sekarrini. (2018). Pengaruh Religiusitas, Tingkat Pendidikan, Tingkat Pendapatan, Terhadap Minat Muzakki Membayar Zakat Maal di Baznas Kabupaten Gorontalo. Skripsi. Yogyakarta: Universitas Islam Negeri Sunan Kalijaga

Makhfudl Bayu Bahrudin. (2017). Efektifitas Penyaluran Dana Zakat di Baznas Provinsi Jawa Timur. Skripsi. Surabaya: Universitas Islam Negeri Sunan Ampel

Mubasirun. (2013). Distribusi Zakat dan Pemberdayaan Ekonomi Umat. Jurnal Penelitian Sosial Keagamaan. Volume 7 (Nomor 2) Pasal 16 UU No. 38 Tahun 1999. Tentang Pengelolaan Zakat.

Mukarromah, oom. Januari-Juni 2016. Keadilan Ekonomi Dalam Pendistribusian Zakat Oleh Badan Amil Zakat Nasional (Baznas) Kabupaten Serang-Banten. bil dalil (Jurnal Hukum Keluarga Islam). Volume 1.

Soemitra, Andri. (2009). Bank dan Lembaga Keuangan Syariah. Jakarta: Prenadamedia Group Sugiyono. (2011). Metode Penelitian Pendidikan Pendekatan Kuantitatif, Kualitatif dan R\&D.

Bandung: Alfabeta Steers, M. Richard. 1985. Efektivitas Organisasi. Jakarta: Erlangga https://republika.co.id/berita/pz4wjo415/atasi-ketimpangan-ekonomi-kebijakan-haruskomprehensif 